\title{
DISERTACIONES
}

ESTUDIOS

Para citar este artigo: Abreu, D., \& de Sousa Lacerda, J. (2022). A ciberpublicidade presente na promoção da transparência na indústria da moda: uma análise da campanha \#quemfezminhasroupas no Instagram. Anuario Electrónico de Estudios en Comunicación Social "Disertaciones", 15(2), 1-22. https://doi. org/10.12804/revistas.urosario.edu.co/disertaciones/a.10573

\section{A CIBERPUBLICIDADE PRESENTE NA PROMOÇÃO DA TRANSPARÊNCIA NA INDÚSTRIA DA MODA: UMA ANÁLISE DA CAMPANHA \#QUEMFEZMINHASROUPAS NO INSTAGRAM *}

\section{La ciberpublicidad presente en la promoción de la transparencia en la industria de la moda: un análisis de la campaña \#quemfezminhasroupas en Instagram \\ Online Advertising, Part of Transparency Promotion in the Fashion Industry: An Analysis of the \#quemfezminhasroupas Campaign in Instagram}

Danielle Correia Neves Abreu, Universidade Federal do Rio Grande do Norte (Brasil) midiasabreu@gmail.com

Juciano de Sousa Lacerda, Universidade Federal do Rio Grande do Norte (Brasil) juciano.lacerda@ufrn.br

Recebido: 07 de maio de 2021 Aprovado: 14 de julho de 2021

Data de pré-publicação: 15 de outubro de 2021

* Versão anterior desse artigo foi apresentada e publicada em junho de 2020 nos anais do evento: xxIx Encontro Anual da Compós, organizado pela Universidade Federal de Mato Grosso do Sul. 


\section{DISERTACIONES}

ESTUDIOS

Economía de la atención: datos, redes sociales y consumos digitales

ISSN: 1856-9536

Doi: https://doi.org/10.12804/revistas.urosario.edu.co/disertaciones/a.10573

Volumen 15, Número 2 / Julio-diciembre 2022

Versión PDF para imprimir desde

http://revistas.urosario.edu.co/index.php/disertaciones

\section{RESUMO}

Este artigo tem como objetivo investigar como marcas brasileiras ligadas ao universo da moda integraram a campanha, coordenada pelo movimento Fashion Revolution, \#quemfezminhasroupas no Instagram. Para isso, foi feito um mapeamento da respectiva hashtag, durante o mês de abril de 2019 na rede social digital Instagram. Desse modo, através dessas postagens, foi possível refletir um pouco a respeito dos bastidores da cadeia produtiva da moda nacional. Nesse sentido, foi possível vislumbrar a partir das publicações encontradas, como as marcas cumpriram os objetivos da campanha \#quemfezminhasroupas. Assim, foram encontradas 297 postagens que somaram 650 imagens, as quais foram submetidas a análises quantitativas e qualitativas. Portanto, após uma análise de conteúdo da respectiva hashtag, os resultados indicaram que as marcas estavam mais envolvidas em promover a interatividade, a relevância e a experiência em detrimento dos principais objetivos da campanha \#quemfezminhasroupas impulsionada pelo Fashion Revolution Brasil.

Palavras-chave: fashion revolution; publicidade; Instagram; sustentabilidade; consumo.

\section{RESUMEN}

Este artículo tiene como objetivo investigar cómo las marcas brasileñas vinculadas al mundo de la moda integraron la campaña, coordinada por el movimiento Fashion Revolution, \#quemfezminhasroupas en Instagram. Para ello, se realizó un mapeo del respectivo hashtag durante el mes de abril de 2019 en la red social Instagram. Así, a través de estas publicaciones, se pudo reflexionar un poco sobre los bastidores de la cadena de producción de moda nacional. En este sentido, se pudo vislumbrar, a partir de las publicaciones encontradas, cómo las marcas cumplieron con los objetivos de la campaña \#quemfezminhasroupas. Así, se encontraron 297 publicaciones con un total de 650 imágenes, las cuales fueron sometidas a análisis cuantitativo y cualitativo. Por tanto, luego de un análisis de contenido del respectivo hashtag, los resultados indicaron que las marcas estaban más involucradas en promover la interactividad, relevancia y experiencia en detrimento de los principales objetivos de la campaña \#quemfezminhasroupas de ropa promovida por Fashion Revolution Brasil.

Palabras clave: fashion revolution; publicidad; Instagram; sostenibilidad; consumo.

\section{ABSTRACT}

This article analyzes how Brazilian fashion brands were incorporated into \#quemfezminhasroupas, a campaign coordinated by the Fashion Revolution movement, via Instagram, a social network site. The corresponding hashtag was mapped in Instagram during April 2019. These posts allowed us to consider the backstage of the national fashion supply chain. Based on the posts found, we observed how brands met the objectives of the \#quemfezminhasroupas campaign. This study found 297 posts, totaling 650 pictures, which were subjected to quantitative and qualitative 


\section{DISERTACIONES}

ESTUDIOS

Economía de la atención: datos, redes sociales y consumos digitales

ISSN: 1856-9536

Doi: https://doi.org/10.12804/revistas.urosario.edu.co/disertaciones/a.10573

Volumen 15, Número 2 / Julio-diciembre 2022

Versión PDF para imprimir desde

http://revistas.urosario.edu.co/index.php/disertaciones

analyses. Therefore, the results of a content analysis of the corresponding hashtag showed that brands were more involved in promoting interactivity, relevance, and experience to the detriment of the main goals of the \#quemfezminhasroupas apparel campaign, promoted by Fashion Revolution Brazil.

Keywords: Fashion revolution; advertising; instagram; sustainability; consumption.

A data era 24 de abril de 2013, quando o Edifício Rana Plaza desabou em Bangladesh com mais de 4.000 funcionários que, no momento, estavam trabalhando em suas dependências. 0 imóvel de oito andares abrigava confeç̧ões responsáveis por abastecer as araras e prateleiras de famosas marcas de roupa em diversos lugares do mundo. Bangladesh está no topo da lista dos maiores exportadores do mundo da moda.

A edificação já havia recebido alerta dos funcionários e de autoridades quanto aos riscos de desabamento, mas mesmo assim suas atividades não foram interrompidas. $O$ caso em questão causou comoção mundial e serviu para fazer as marcas de moda refletirem sobre sua cadeia produtiva junto com os consumidores. A partir dessa tragédia, nasceu o movimento Fashion Revolution que acontece durante toda a semana do dia 24/04 em alusão a data em que ocorrera a tragédia. Assim, essa semana é marcada por atividades que buscam promover a reflexão sobre o consumo e produção de moda.

Nesse ínterim, as redes sociais funcionaram como mola propulsora do movimento, tanto conquistando a empatia dos usuários, como fazendo com que diversas marcas passassem a mostrar que apoiam a causa, adicionando valores e preocupações sociais à sua imagem. Desse modo, dentro do movimento Fashion Revolution surgiu no Instagram a campanha \#quemfezminhasroupas, cujo objetivo é estimular a curiosidade das pessoas para questionarem a origem de suas vestimentas e fazer as marcas tornarem transparentes seus processos produtivos.

Além de enxergar as etapas produtivas das peças, a campanha foca em mostrar quem é a pessoa que está produzindo suas roupas. Assim, as marcas são convidadas a apresentar seus funcionários, seus fornecedores e suas condições de trabalho. A ideia é que durante a semana do Fashion Revolution os consumidores postem no Instagram a imagem da etiqueta de suas roupas e marquem na legenda o perfil da marca com a \#quemfezminhasroupas. Em contrapartida, as marcas devem responder com foto e/ou vídeo apresentando e contando um pouco da história das pessoas envolvidas no processo.

Essa hashtag, devido ao crescimento do movimento, apresenta uso no decorrer de todo o ano, porém com propostas diferentes de sua demanda inicial, como por exemplo, a divulgação de peças e coleções novas. Contudo, isso vai na contramão da ideologia do movimento que visa reeducar as pessoas quanto aos seus hábitos de consumo, entendendo que o ciclo da peça não termina no ato da compra, pois também deve existir responsabilidade com o descarte. Desse modo, o movimento também sugere uma ponderação à produção e à compra desenfreada. 


\section{DISERTACIONES}

ESTUDIOS

Economía de la atención: datos, redes sociales y consumos digitales

ISSN: 1856-9536

Doi: https://doi.org/10.12804/revistas.urosario.edu.co/disertaciones/a.10573

Volumen 15, Número 2 / Julio-diciembre 2022

Versión PDF para imprimir desde

Estima-se que é dispensado um caminhão de lixo de têxteis a cada segundo em diversos aterros sanitários espaIhados pelo mundo. $O$ tratamento e lavagem do poliéster, por exemplo, fibra popular na confecção de roupas, lança ao mar, anualmente, meio milhão de toneladas de microplásticos (Ellen Macarthur Foundation, s. f.). Dados como esses estão servindo de alerta para que sejam repensados antigos padrões e condutas aceitas na moda até então.

A alta rotatividade da moda pode ser um indicativo de abusos e exploração do meio ambiente e da mão de obra trabalhista. A sustentabilidade é uma discussão ambiental e social que muitas vezes tende a cair no "panfletário" e no modismo. Nesse cenário, várias marcas de moda no Instagram se apresentam como adeptas do Slowfashion, ${ }^{1}$ autorais ou locais. Assim, elas acionam esses valores em suas estratégias de marketing e publicidade.

Destarte, esse artigo se debruça a analisar a performance das empresas de moda ao usarem a \#quemfezminhasroupas durante o mês de abril de 2019 no Instagram. Iremos investigar se o conjunto de postagens atenderam ou não aos ideais do movimento Fashion Revolution. Assim, questionamos: tais postagens corresponderam ao chamado da campanha em ser transparentes quanto às relações de trabalho e cadeia produtiva? Os compartiIhamentos realizados pelas marcas de moda brasileira que aderiram à campanha corresponderam aos objetivos da \#quemfezminhasroupas? Essas questões encontram-se amalgamadas à publicidade contemporânea e formam discussões que refletem os mais diversos paradoxos da nossa sociedade. Por isso, se torna um tema importante a ser discutido pela perspectiva da comunicação.

Estudos anteriores (Martins, 2019; Pereira, 2019; Vargas, 2018) evidenciam que o posicionamento das marcas em temáticas que envolvem questões sustentáveis pode fortalecer o branding, exigindo das marcas uma responsabilidade maior frente às mudanças da sociedade. Contudo, esses estudos tem em comum o fato de que, de alguma forma, eles ressaltam que as ações dentro da vivência corporativa devem corresponder a essas estratégias para que possam construir uma real relevância frente ao cenário competitivo instaurado no mundo da moda. Sendo assim, utilizar esse posicionamento e acionar as ferramentas de Branded Content nas redes sociais em torno de conteúdos que ativam a responsabilidade social é uma forma de atrair a atenção dos usuários e interagir com eles (Castillo-Abdul, Bonilla-del-Río, Núñez-Barriopedro, 2021).

\section{O Instagram como aliado na construção da imagem da marca}

O Instagram vem chamando a atenção das empresas graças a sua predisposição em aumentar o engajamento dos usuários com a marca. Ao final de 2018, a Socialbakers ${ }^{2}$ mostrou que o Instagram, embora não seja a rede social com maior número de seguidores, é a mais favorável ao engajamento (Socialbakers, 2021). Com isso, o Instagram

1 Movimento que tem forte preocupação com toda cadeia produtiva da moda, desde o cultivo do algodão, por exemplo, até o descarte dessas peças. Porventura, são peças bem mais caras, pois a ideia é que elas não sejam facilmente descartáveis, durem bastante e sejam neutras e atemporais. Além disso, são peças fabricadas e vendidas em pequena escala. Isso garante $\mathrm{o}$ ar de exclusividade para os clientes.

2 "Socialbakers is a global Al-powered social media marketing company offering a marketing software-as-aservice platform called the Socialbakers Suite. It is used by brands like McDonalds, L'Oreal and Desigual for social media marketing on Facebook, Instagram, Twitter, YouTube, LinkedIn, Google+, VK, and Pinterest." Disponível em: < https://en.wikipedia.org/wiki/Socialbakers >. 


\section{DISERTACIONES}

ESTUDIOS

Economía de la at:

ISSN: 1856-9536

Doi: https://doi.org/10.12804/revistas.urosario.edu.co/disertaciones/a.10573

Volumen 15, Número 2 / Julio-diciembre 2022

Versión PDF para imprimir desde

http://revistas.urosario.edu.co/index.php/disertaciones

se transformou em palco de performances que buscam se aproximar do público, não apenas através de seus produtos ou serviços, mas também através de sua identidade e seus valores.

No Instagram é habitual que usuários procurem se conectar com as marcas que admiram. Dados revelam que mais de $80 \%$ das contas ativas no Instagram seguem ao menos um perfil de empresa (Instagram, 2021). Essa relação parte do princípio de que a publicidade ancorada na cibercultura reconfigurou suas práticas discursivas para se inserir no contexto digital (Carrera, 2018). Assim, estabelecer uma relação de maior horizontalidade com o consumidor se tornou o foco dessas marcas. A expectativa é que o conteúdo e a identidade da marca sejam capazes de instigar a interação desses consumidores.

Nesse ínterim, construir afinidades com seu público se torna projeto estratégico no campo das estratégias midiáticas. Sendo assim, tais aspectos sobre a publicidade contemporânea se concretizam através do conceito de ciberpublicidade que se sustenta nos pilares da interatividade, da relevância e da experiência (Atem et al., 2014).

Desse modo, compreende-se que os recursos disponíveis no Instagram, tais como a possibilidade de seguir hashtags, os Stories, a seção Explore, dentre outros, compõe interessantes possibilidades de destacar a marca perante seu público. Assim, a iniciativa de promover a campanha do Fashion Revolution através de uma hashtag cede às marcas um espaço para que elas se mostrem comprometidas com questões que vão além da venda do produto. Contudo, também possibilita que ações, meramente, performáticas sem vínculos reais com as práticas internas atinjam mais rapidamente um público interessado nesse tipo de assunto.

É fato que a ascensão das redes sociais ampliou o papel do consumidor e por isso, as marcas precisam lidar com críticas e questionamentos constantes. Por outro lado, "the growth and development of media culture has created a society where people need advanced skills of media literacy and visual literacy"33 (Malmelin, 2010, p. 131). Ou seja, o autor em questão defende o desenvolvimento de uma literacia em prol da publicidade. Esse tipo de habilidade pode, por exemplo, inibir que qualquer selo verde, posto por designers em diversas embalagens de produtos, sejam automaticamente vinculados a uma postura de sustentabilidade. Ao invés disso, o consumidor adquire a capacidade de estabelecer uma crítica menos superficial em cima desse elemento visual.

Do ponto de vista da ciberpublicidade, o universo do Instagram se tornou uma forma interessante de projetar a marca no ambiente digital. $O$ fato é que os recursos digitais dispostos nas redes sociais turbinam as possibilidades de interação da marca com seu público. Não obstante, é preciso pensar que à medida que cresceram as cobranças e articulação da sociedade por mudanças, também cresceram recursos e possibilidades de manipular e maquiar, dando a ilusão de mudança e preservando as atuais relações de poder.

\section{Ciberpublicidade e suas implicações}

A nossa sociedade ao vislumbrar o início de uma web semântica (Santaella, 2013) vive um momento de constante reconfiguração (Lemos, 2005) e com a publicidade não poderia ser diferente. Em meio aos usuários multitelas, convergentes (Jenkins, 2009), com redes sociais como suporte para interações (Recuero, 2009), a publicidade

3 O crescimento e desenvolvimento da cultura da mídia criou uma sociedade onde as pessoas precisam de habilidades avançadas em alfabetização midiática e visual (Tradução nossa). 


\section{DISERTACIONES}

ESTUDIOS

Economía de la ater

ISSN: $1856-9536$

Doi: https://doi.org/10.12804/revistas.urosario.edu.co/disertaciones/a.1057.3

Volumen 15, Número 2 / Julio-diciembre 2022

Versión PDF para imprimir desde

http://revistas.urosario.edu.co/index.php/disertaciones

percebeu que precisava ir além do seu produto ou serviço. Ou seja, para preservar seu vínculo contratual (Verón, 2005) se fez necessário à publicidade potencializar sua capacidade de produzir conteúdo.

A expansão dessa produção de conteúdo é notável, naturalmente, nas redes sociais. Nesse espaço elas precisam se adequar a diferentes dispositivos - Stories, feeds, timelines, anúncios on-line etc. - para ser capaz de engajar os usuários fazendo com que se identifiquem com os conteúdos produzidos.

Tais constatações já foram afirmadas e embasadas em diferentes estudos no campo da publicidade, os quais podemos citar alguns (Atem et al., 2014; Carrera, 2018; Perez, 2009; Perez \& Aquino, 2018). $O$ destaque desses estudos é justamente refletir as dinâmicas da publicidade dentro da sociedade contemporânea, instauradas através de parâmetros sociotécnicos.

Assim, as marcas vão construindo uma imagem dentro de uma lógica transmidiática (Jenkins, 2009), que expõe aos consumidores fragmentos, distintos entre si, mas complementares por serem capazes de imprimir sua identidade na forma de um arco narrativo coerente. Desse modo, os rituais de consumo se ampliam e a produção de conteúdo passa a fazer parte da experiência do cotidiano de marcas interessadas em conquistar o interesse de diferentes pessoas.

A complexidade pós-moderna questiona fortemente a ideia do target (Verón, 2005; Perez, 2009) e nesse cenário as marcas são convocadas a construírem narrativas sociotécnicas contundentes com o mundo atual. Eis que a publicidade adentra relações em que "a comunicação da imaterialidade, o valor da subjetividade, o crescimento simbólico e o entendimento dos valores sociais" (Perez \& Aquino, 2018, p.311) aparecem como elementares no que diz respeito aos atuais elos entre marcas e consumidores. Elos que se constroem também por processos de "desfocalização" ao produzir relações culturais e simbólicas entre marcas e consumidores, para além da "pertinência direta" almejada na concepção do target (Verón, 2005).

A necessidade de propósitos capazes de formar narrativas esperadas pelo público, fortalece a aparição de estratégias que buscam discutir sustentabilidade e o empoderamento das minorias. Contudo, compreender quando o femvertising, ${ }^{4}$ por exemplo, vai além da representação e realmente está presente no backstage da marca não é uma tarefa fácil. "Assim como os indivíduos negociam e flexibilizam o ideal de representação verdadeira de si mesmo, as marcas também vivem buscando elementos e cenários para a construção de uma fachada verossímil de sua identidade" (Carrera, 2018, p.249).

Como exemplo podemos citar o caso da Loja Três, uma marca de moda autoral que se apresentava como inclusiva, fazendo diversas campanhas on-line e off-line para fortalecer essa imagem perante o público. Algumas das ações envolviam adicionar às peças compradas a foto da pessoa colaboradora responsável pela produção do produto. No site um videoclipe mostra os funcionários em sala de costura dançando e felizes, além de um clipe com a cantora Mahmundi, ${ }^{5}$ são alguns exemplos de peças que foram bastante divulgadas em suas redes sociais. Ou seja, eram muitos os esforços em publicidade para tornar robusta a imagem de uma marca que zela por respeito e ideais de igualdade.

4 Se refere a publicidade voltada ao empoderamento feminino.

5 Cantora negra vinda da periferia que encontrou na música espaço e sucesso. Inclusive, em seu disco lançado em 2016, ela dedicou os agradecimentos a cinco jovens mortos em Madureira (RJ) pela polícia do Rio de Janeiro em 2015. 


\section{DISERTACIONES}

A imagem da marca caiu por terra quando em maio de 2019, funcionários e ex-funcionários denunciaram, em reportagem assinada pelo Uol (Gonzalez, 2019), casos de gordofobia, racismo, homofobia e assédio moral. Ao total foram 11 pessoas ouvidas pela reportagem. Os relatos envolvem execução de trabalho por mais de 11 dias sem folga, sem troca de uniformes, coação para desfazerem dreads que possuíam no cabelo, pois segundo a proprietária era "coisa de gente da comunidade", orientação para não contratar mães com filhos pequenos, nem homossexuais, tampouco pessoas que estivessem acima do peso.

Esse caso é apenas um exemplo que elucida algumas questões sobre a ciberpublicidade e chama atenção sobre o quanto é complexo construir imagens vazias em tempos de interatividade e transparência. Quando voltamos o olhar para sustentabilidade ambiental também nos deparamos com iniciativas que focam em ludibriar o consumidor. O greenwashing ${ }^{6}$ usa de frases de impactos, palavras dúbias que levam o consumidor a acreditar que a marca está consciente quanto ao meio-ambiente. Casos dessa natureza levaram o conAr a definir normas para combater o greenwashing na publicidade, instauradas desde 2011.

Tais situações mostram que a responsabilidade da marca se insere em diversos contextos, pois as relações sociotécnicas presentes em nosso cotidiano destacam o potencial da marca em comunicar e atuar nessas relações, "a marca é mídia" (Perez, 2016, p. 8). As redes sociais tem papel fundamental como artefato potencializador dessas relações. Diariamente, surgem diferentes recursos para dar suporte e ativar o lúdico entre os atores sociais envolvidos em diferentes processos de interação e socialização.

Nesse sentido, no Instagram a marcação de hashtags se transforma em um espaço possível para desenvolver essa narrativa. Assim, ao fazer a marcação da \#quemfezminhasroupas as marcas de moda conseguem se encaixar no movimento Fashion Revolution e criar conexões com os usuários que simpatizam com o movimento. Oespaço consegue aliar, satisfatoriamente, a relevância, a interatividade e a experiência, gerando conteúdo e criando assunto com essas pessoas.

Além disso, se torna uma forma de levar os valores da campanha para si. Claro que a construção da imagem da marca vai além desse espaço e recurso, mas para fins deste trabalho o objetivo não é analisar o discurso como um todo de nenhuma marca específica, pois o foco é refletir apenas sobre o espaço da hashtag: \#quemfezminhasroupas.

Por isso, foi necessário pontuar sobre a publicidade em nossos dias para direcionarmos um olhar mais crítico a essas postagens. Uma vez explicado sobre o movimento Fashion Revolution e sobre alguns dos parâmetros nos quais a publicidade está inserida poderemos tensionar os interesses dessas publicações com os interesses do movimento.

6 A tradução do termo significa maquiagem verde e se refere a ações de publicidade enganosas quanto a temática da sustentabilidade. 


\section{DISERTACIONES}

ESTUDIOS

Economía de la atención: datos, redes sociales y consumos digitales

ISSN: 1856-9536

Doi: https://doi.org/10.12804/revistas.urosario.edu.co/disertaciones/a.1057.3

Volumen 15, Número 2 / Julio-diciembre 2022

Versión PDF para imprimir desde

http://revistas.urosario.edu.co/index.php/disertaciones

\section{A sustentabilidade e as minorias no mercado de moda no Brasil}

O Brasil ocupa a posição de quarto maior produtor de malhas do mundo, além disso a nossa indústria têxtil é a maior e mais completa em todo o ocidente (Abit, s. f.). Consequentemente, esses dados fazem desse setor o segundo maior empregador na indústria de transformação, sendo o segmento de confecção responsável por $75 \%$ desses empregos. Nesse percentual, a presença feminina se faz majoritária e corresponde a $73 \%$ das vagas ocupadas. ${ }^{7}$

No cenário global, mesmo diante da forte presença feminina, os cargos da alta direção em grandes empresas são destinados a homens. Dentre as 50 maiores empresas de moda no mundo apenas $14 \%$ delas são lideradas por mulheres (Johnson, 2015). Quando direcionamos esse olhar para as mulheres negras, a disparidade fica ainda maior. Recentemente, uma mulher negra conseguiu chegar ao topo de uma marca de luxo. Em maio de 2019, a cantora Rihanna lançou a Fenty (O Globo, 2019), uma marca de moda vinculada ao grupo Lvмн. ${ }^{8}$ Desse modo, esse dado nos faz refletir se as marcas aplicam na sua prática cotidiana os mesmos esforços que usam para mostrarem o quanto são inclusivas.

Nas passarelas é reiterado o culto ao padrão eurocêntrico. Na São Paulo Fashion Week, por exemplo, foi preciso um código de conduta, assinado em 2009, frente ao ministério público no intuito de garantir que pelo menos $10 \%$ do casting de modelos fossem negras $(\mathrm{G} 1,2009)$. Decerto, sobram reclamações de que esse acordo não está sendo cumprido (Cruz, 2015).

Apesar dos esforços em mudar tal cenário excludente, o que vemos nas passarelas é a perpetuação das raízes de dominação de uma sociedade, ainda, machista, racista, gordofóbica, classista e homofóbica. Em dezembro de 2018, o diretor de marketing da famosa marca Victoria's Secret afirmou publicamente seu desinteresse em contratar modelos transgêneros e plus size (Querino, 2019).

Contudo, em tempos de redes sociais tal afirmação não passou batida e a marca lançou nota com pedidos de desculpas sobre sua declaração (Veja, 2018). As redes sociais turbinadas pelo fenômeno da mobilidade colocam marcas e atores sociais em um mútuo esquema de interação. Assim, a capacidade de engajar os usuários frente aos mais diversos debates está levantando a necessidade das marcas se adequarem para atender as exigências dos clientes que cada vez mais buscam se conscientizar e se informar com o apoio da internet. Entretanto, existe a possibilidade de que essa adequação seja apenas monetização de tais discursos para deslumbrar minorias que começam a conquistar sua independência financeira.

A ascensão da mulher no mercado de trabalho e sua busca pela independência financeira estão fazendo a publicidade rever seu discurso. $\mathrm{O}$ foco é atrair a atenção feminina, esgotada das inúmeras campanhas que representavam

7 Disponível em https://bucket-gw-cni-static-cms-si.s3.amazonaws.com/media/filer_public/bb/6f/bb6fdd8d-8201-41ca-981d-deef4f58461f/abit.pdf

8 “LVMH Moët Hennessy Louis Vuitton SE Ou simplesmente LvMH, é uma holding francesa especializada em artigos de luxo. Foi formado pelas fusões dos grupos Moët et Chandon e Hennessy e, posteriormente, do grupo resultante com a Louis Vuitton.” Disponível em https://pt.wikipedia.org/wiki/LVMH 


\section{DISERTACIONES}

ESTUDIOS

Economía de la atención: datos, redes sociales y consumos digitales

ISSN: 1856-9536

Doi: https://doi.org/10.12804/revistas.urosario.edu.co/disertaciones/a.1057.3

Volumen 15, Número 2 / Julio-diciembre 2022

Versión PDF para imprimir desde

http://revistas.urosario.edu.co/index.php/disertaciones

as mulheres nos mesmos velhos papéis de objetificação ou subserviência (Silva \& Costa, 2017). ${ }^{9}$ Dito isto, vemos que discussões a respeito das minorias se tornaram frequentes. A moda se insere no complexo paradoxo de mostrar o novo, ser subversiva, mas sem romper com as raízes de dominação da nossa sociedade. Contudo, a web 2.0 ajudou a ampliar o clamor social pelo rompimento de tais paradoxos e um novo desafio foi instaurado: promover o diálogo com seu público através da transparência em uma relação de horizontalidade entre ambos.

Uma compreensão ampla da sustentabilidade vai de encontro ao bem-estar humano, à qualidade de vida e, portanto, uma sociedade mais igualitária a todos. Esse encontro envolve dimensões social, cultural, ecológica, ambiental, econômica, territorial, política nacional e política internacional (Sachs, 2004). Assim, a publicidade se insere nesse debate, mas é preciso um olhar mais atento para captar até que ponto todo esse discurso não se configura apenas como estratégia de venda. $\mathrm{O}$ fato é que se tornou um operador semântico popular entre diversas marcas, não apenas de moda, abordar sustentabilidade em suas campanhas.

O mundo da moda, as redes sociais, a sustentabilidade e a publicidade juntos somam variáveis complexas que resultam em discussões que vão além do espaço desse texto. Portanto, sabemos que o assunto rende além dos exemplos e dados aqui expostos, pois há muito o que ser esmiuçado sobre tais questões.

A moda como reflexo dos mais diversos estigmas da nossa sociedade encontra nas redes sociais ambiente propício ao debate e se apoia na ciberpublicidade para construir uma imagem que inspire a credibilidade das pessoas. Dos bastidores da moda às passarelas, a moda veio por muitos anos alimentando padrões e pouco fazendo para romper com tais estigmas. Dessa maneira, o ciclo de manutenção de tais parâmetros se retroalimenta e "a sociedade estabelece os meios de categorizar as pessoas e o total de atributos considerados como comuns e naturais para os membros de cada uma dessas categorias" (Goffman, 1981, p.5).

\section{Metodologia}

Foi escolhido analisar a hashtag: \#quemfezminhasroupas no Instagram durante o mês de abril, visto que é nesse mês que acontece a programação do movimento Fashion Revolution. Assim, a proposta é analisar as postagens das marcas que aderiram à campanha no ano de 2019. Na página idealizadora do movimento no Instagram (@fash_rev_brasil) existe um passo a passo, destinado às marcas, publicado na seção de destaque dos Stories. Nesse tutorial é solicitado que a marca imprima uma placa, disponibilizada através de link, com o texto "Eu fiz suas roupas", em seguida a marca é orientada a fotografar pessoas da equipe de produção em seu ambiente de trabalho segurando a placa que foi impressa anteriormente.

O terceiro passo desse tutorial fala sobre mostrar as instalações e contar a história dessas pessoas que foram fotografadas e que ajudaram a produzir a roupa. Por fim, o último passo corresponde a orientação de marcar o perfil do Fashion Revolution Brasil e usar a hashtag \#eufizsuasroupas.

9 Este artigo (Publicidade, empoderamento feminino e o reposicionamento da cerveja Itaipava) traz um exemplo bem interessante sobre reposicionamento da marca quanto ao papel da mulher em sua publicidade. 



Figura 1. Tutorial de como as marcas devem participar do movimento Fashion Revolution

Fonte: Seção de destaque dos Stories no Instagram @fashionrevolution

Como se pode ver, está dentro das orientações da campanha contar um pouco da história desses profissionais como forma de mostrar o lado humano de todo esse processo, além de nos proporcionar a visão dessas fábricas, confecções e ambientes de trabalhos que compõem toda a cadeia produtiva da moda. Baseado nisso, elencamos duas variáveis a serem investigadas. A primeira diz respeito a se estavam sendo exibidos ou não os locais de trabalho e, a segunda, se concentra na parte de observação textual para identificar se foi ou não revelado um pouco da história da pessoa registrada em foto com a placa.

A hashtag \#quemfezminhasroupas tem mais de 45.000 publicações realizadas desde 2014, data início de seu surgimento, enquanto a \#eufizsuasroupas tem em torno de 5.000 imagens. Nesse primeiro momento, optamos por investigar a \#quemfezminhasroupas pelo fato dela ter mais publicações e porque foi observado que ela costuma vir acompanhada da \#eufizsuasroupas. Desse modo, mesmo com as pessoas usando a hashtag de resposta, a hashtag que questiona também aparecia nas marcações. O movimento mais intenso da \#quemfezminhasroupas se dá pelo motivo dela servir de título para a campanha, resultando em uma maior apropriação por conta dos usuários que usam a hashtag em questão para diversos fins como, por exemplo, lançamentos, tendências etc.

O próximo passo foi definir como se daria a sistematização dos resultados a serem trabalhados. No Instagram existem duas formas de ordenar as postagens por hashtags: elas podem ser visualizadas de acordo com a relevância ou de forma cronológica a partir das postagens mais recentes. Para obter um resultado menos moldado pelos algoritmos do Instagram, optamos por analisar a partir das mais recentes. Do contrário, teríamos como resultado imagens impulsionadas pela aprendizagem de máquina que direciona o resultado para o uso que o usuário faz de sua rede.

Com a seleção definida, passamos a separar as imagens de acordo com seu enquadramento. Em relação ao texto que acompanha essas imagens a análise buscou identificar se era nominada e descrita qualitativamente a pessoa mostrada como responsável pela produção da roupa. Entre as 4650 postagens, publicadas no mês de abril 


\section{DISERTACIONES}

com a hashtag \#quemfezminhsroupas, detectamos 297 postagens de marcas de moda participantes da campanha Fashion Revolution. Somando os resultados das imagens de fotos e recortes das cenas de vídeos, chegamos ao total de 650 imagens ${ }^{10}$ acompanhadas por 297 textos. As imagens se dividiram da seguinte forma: 397 fotografias e 22 vídeos que resultaram em 253 planos de cenas. Quanto aos textos que acompanhavam essas 297 postagens, apenas 26 desses compartilhamentos se dedicaram a apresentar a(s) pessoa(s) retratada(s) em cena indo além de sua função na empresa, destacando qualidades e apresentando um pouco de sua história ou alguma curiosidade sobre ela.

A observação dessas imagens se sustenta no método de análise de conteúdo sobre uma perspectiva que busca levantar inferências qualitativas e se apoia em dados quantificáveis como complementares. Ademais, a visão da metodologia abordada está centrada para que não se vincule excessivamente à técnica, "num formalismo excessivo, que prejudique a criatividade e a capacidade intuitiva do pesquisador, por conseguinte, nem tão subjetiva, levando-se a impor as suas próprias ideias ou valores, no qual o texto passe a funcionar meramente como confirmador dessas" (Campos, 2004, p. 613). Desse modo, a presente pesquisa utiliza dados numéricos para um enfoque predominantemente qualitativo, pois não há pretensão de inferências estatísticas com esse estudo, mas, sim, descortinar resultados descritivos e interpretativos a respeito do objeto em análise. Bardin (2016) enfatiza que o método de análise de conteúdo pode ser usado em pesquisas qualitativas, podendo, inclusive, fazer uso de formas de quantificação. Dito isso, ressalta-se que o corpus foi analisado a partir da ausência ou presença de elementos que evidenciavam o quanto essas imagens estavam enquadradas no objetivo da campanha \#quemfezminhasroupas. "Em conclusão, pode dizer-se que o que caracteriza a análise qualitativa o fato de a "inferência -sempre que é realizada - ser fundada na presença do índice (tema, palavra, personagem etc.!), e não sobre a frequência da sua aparição, em cada comunicação individual” (Bardin, 2016, p. 146).

Sendo assim, tivemos 3 importantes fases para a análise: "1) pré-análise, 2) exploração do material e 3) tratamento dos resultados" (Bardin, 2016, p. 125). De acordo com esse protocolo, a pré-análise corresponde à organização e sistematização dos dados. Desse modo, ocorreu nessa fase a escolha dos conteúdos a serem analisados, bem como as hipóteses e os objetivos a serem alcançados. No segundo momento foi realizada a análise do material e destrinchadas as imagens de maneira a compreendermos através de seus enquadramentos e composições o quanto elas estavam inseridas no objetivo da campanha \#quemfezminhasroupas. Por fim, a fase interpretativa que, de acordo com análise de conteúdo, acontece a partir da condensação dos resultados em quadros, figuras, gráficos etc. Após cumpridas essas etapas, a análise desse material permitiu avaliar se as imagens corresponderam aos norteamentos básicos, expostos aqui, solicitados pelo movimento Fashion Revolution Brasil, através de sua página própria no Instagram ou se elas ressignificaram o sentido da campanha.

Ressalta-se que partimos da perspectiva de que "o consumo ultrapassa a materialidade dos bens e envolve a associação com uma visão de mundo" (Casaqui, 2014, p. 32). Essa visão lançou luz em torno dos gradientes presentes na manutenção e construção do habitus de consumo inserido no "contrato de leitura" firmado através dessas imagens (Verón, 2005). Assim, o olhar ao empírico dessa pesquisa foi educado a compreender que as imagens buscavam através do simbólico fortalecer esse vínculo da marca com os usuários.

10 Todas as imagens da amostra podem ser acessadas através do seguinte link: https://www.dropbox.com/ sh/zvp4uyfqoyxpr3p/AAC6wrCDLIqcET5AF318cA7pa?dl=0 


\section{DISERTACIONES}

ESTUDIOS

\section{Resultados}

\section{Registros em fotos}

As postagens em formato fotográfico encontradas durante o mês de abril de 2019 com a \#quemfezminhasroupas foram divididas de acordo com seu enquadramento. Ao todo foram 397 fotografias que podemos destrinchá-las nos seguintes planos: 1) plano geral, 2) plano conjunto, 3) meio primeiro plano, 4) primeiro plano, 5) primeiríssimo primeiro plano, 6) plano detalhe. ${ }^{11}$ Através do recorte dos registros de cenas tentamos visualizar o enquadramento que determina essas realidades, ampliando o sentido de enquadramento para aquilo que determina as ações e as relações entre pessoas e seus respectivos papéis configurados por estatutos de participação desses indivíduos (Goffman, 1993 como citado em Nunes, 1986).

Começando pelo plano geral, relatamos que foram encontradas apenas três imagens. Contudo, elas não mostravam muito do ambiente, pois todo o espaço a ser mostrado estava preenchido por inúmeras pessoas aglomeradas em pé, uma ao lado da outra, pousando para a foto. Isso dificultava a visão do ambiente de trabalho como um todo.

Enquadradas como plano conjunto, foi possível encontrar 53 imagens, das quais 29 exibiam as pessoas em suas estações de trabalho, sejam elas mesa de corte, máquinas de costura, de estampa, dentre outras. Contudo, no que diz respeito aos objetos mais próximos, as imagens favoreciam um ângulo em que se via apenas a pessoa e a máquina de uma forma que não conseguíamos ver sua estação de trabalho por completo, à medida que deslocávamos a visão ao fundo da imagem, víamos de uma forma mais completa o ambiente em segundo plano, entretanto, não se trata de uma visão que realmente revele as acomodações desses funcionários, como por exemplo, sua cadeira e estação de trabalho. Isso foi percebido, principalmente, quanto às costureiras em que o enquadramento foi ampliado exibindo mais pessoas na cena, mas, ainda, sem a visão completa de sua estação de trabalho, configurando a imagem apenas em máquina e corpo.

11 Plano geral - enquadramento visual aberto, exibe pessoa(s) e ambiente;

Plano conjunto - menos aberto que o plano geral. Revela um pouco do espaço e o registro se aproxima um pouco mais das pessoas dispostas em cena que no plano anterior;

Meio primeiro plano - a pessoa é exibida da cintura para cima e ocupa bastante espaço de toda a imagem; Primeiro plano - registro mais fechado feito a partir do busto da pessoa;

Primeiríssimo primeiro plano - exibe apenas o rosto da pessoa;

Plano detalhe - imagem bastante fechada exibe apenas partes de pessoa ou objeto em cena. 

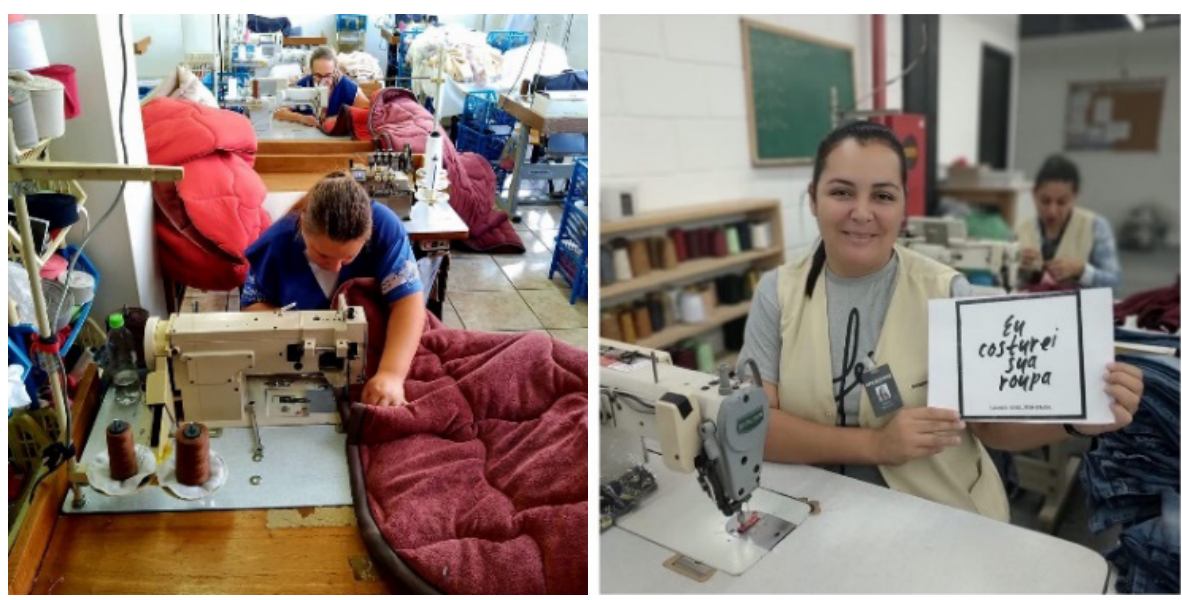

Figura 2. Exemplos de imagens em plano conjunto marcadas com \#quemfezminhasroupas

Fonte: Instagram (2019).

Em plano conjunto foi possível visualizar a estação de trabalho dessas costureiras de forma completa apenas nove vezes. Desse total, em seis vezes foi identificado cadeiras com acolchoados e encostos gastos, compensados com o uso de almofadas e até mesmo cadeira de ferro e madeira. Considerando que são pelo menos sete horas diárias sentadas nessas cadeiras podemos concluir o quão prejudicial a rotina de trabalho pode ser para essas pessoas. Quanto às outras três, as imagens sugerem estações mais confortáveis com cadeiras preservadas e reguláveis. Decerto, estamos diante de um número muito pequeno diante daquilo que deveria ser o principal a ser exibido para a campanha.

O enquadramento meio primeiro plano foi o preferido pelas marcas para mostrar seus funcionários. Ele foi usado 294 vezes. Foi observado duas frequências nessas aparições: ou essas imagens apareciam de forma bem fechada na pessoa e sua máquina/ferramenta de trabalho ou as pessoas eram fotografadas segurando a placa da campanha com uma parede, estante, arara de roupas ou prateleiras de fundo. Ou seja, era o ambiente da empresa, mas exibido de forma ainda mais contida, com a pessoa posicionada em pé no background escolhido.

Desse modo, no formato pessoa e sua máquina/ferramenta de trabalho foram 165 aparições. Já a formatação pessoa(s) com fundo programado aconteceu 129 vezes. No primeiro caso as imagens eram tão fechadas na pessoa e sua máquina, seja de costura ou computadores, que mais uma vez não tínhamos a visão como um todo.

Apenas em 12 imagens foi possível visualizar um pouco mais. Nesse caso, os registros não foram muito diferentes do que ocorrera com o enquadramento meio primeiro plano. As ocorrências foram de assentos desconfortáveis com acolchoado gastos compensados com almofadas sobrepostas, cadeiras de ferro, madeira e até mesmo bancos que sequer apoiavam as costas. 


\section{DISERTACIONES}

ESTUDIOS
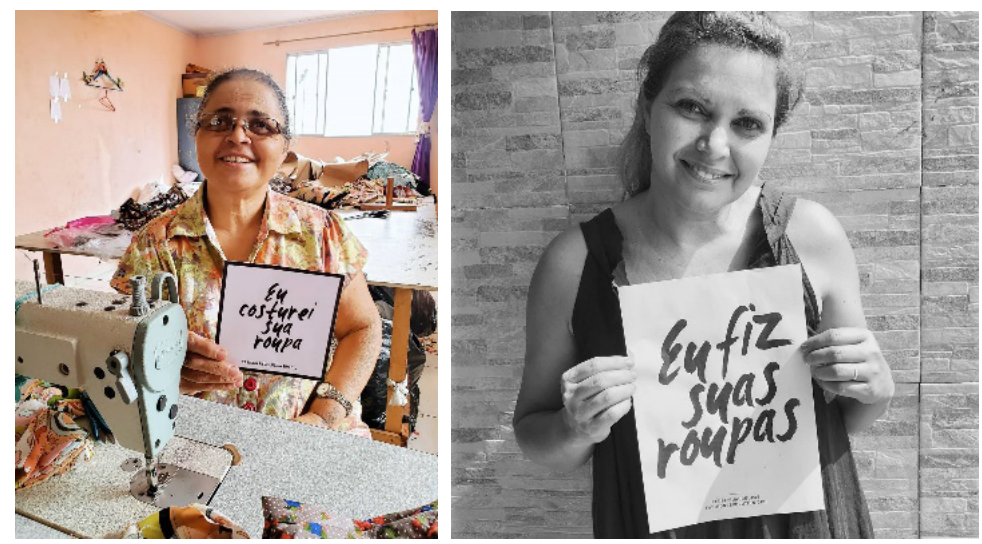

Figura 3. Exemplos de imagens em meio primeiro plano marcadas com \#quemfezminhasroupas

Fonte: Instagram (2019).

As postagens enquadradas como primeiro plano contabilizaram 23 publicações, das quais 12 foram compostas de forma ainda mais fechada na pessoa e sua máquina, mesmo que para isso fosse necessário cortar um pouco da pessoa para compor uma junção de apenas busto humano e máquina em cena. Outras oito imagens desse recorte mostravam pessoas segurando a placa, foto fechada em busto, sem visão do ambiente e uma parede como background da imagem. Por fim, as três fotografias restantes mostraram uma parte da pessoa e o produto que fabricam, no qual duas vezes o foco esteve no produto, desfocando o rosto do fotografado e a outra manteve o foco em ambos, mas sem enquadrar o rosto da pessoa.
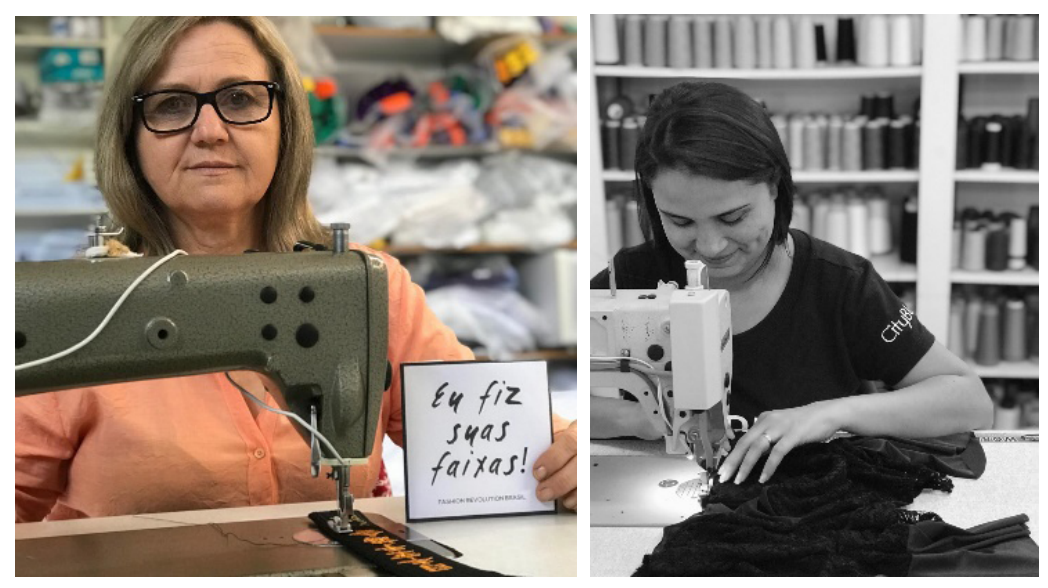

Figura 4. Exemplos de imagens em primeiro plano marcadas com \#quemfezminhasroupas

Fonte: Instagram (2019). 
O enquadramento primeiríssimo primeiro plano ocorreu apenas sete vezes e retratava apenas o rosto da pessoa fotografada. $O$ plano detalhe constou de 14 registros que se concentraram em fechar a imagem apenas em mãos, máquinas e produtos sendo fabricados.

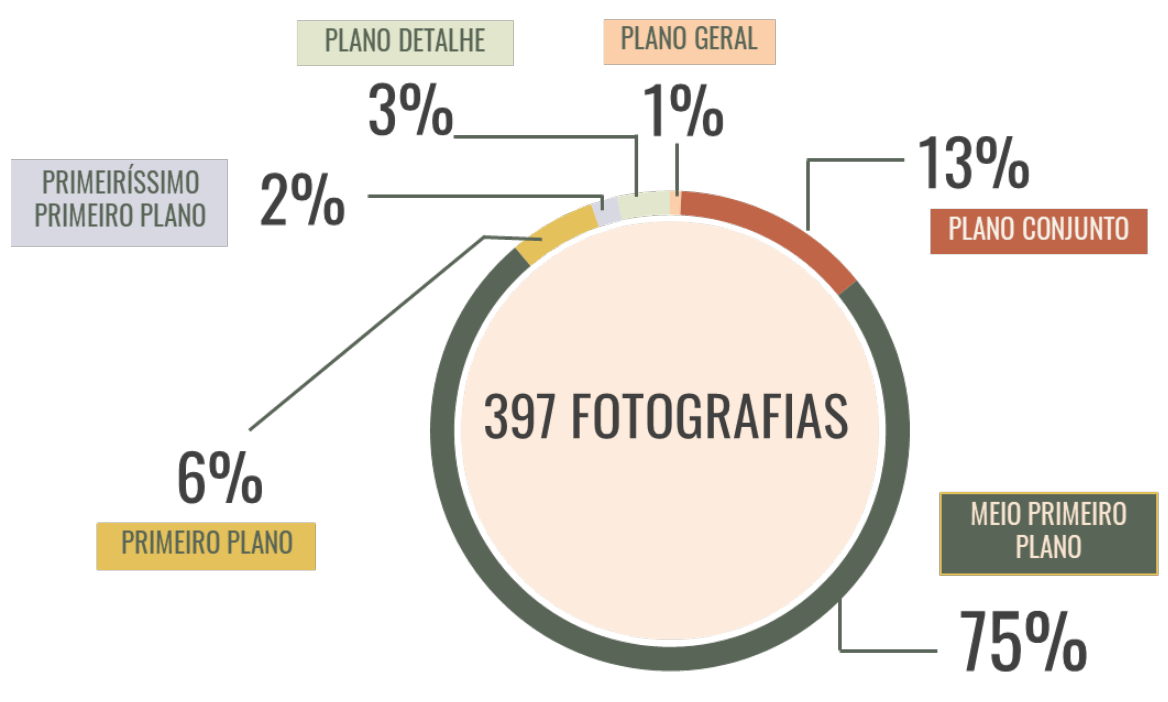

Figura 5. Síntese dos resultados encontrados nas fotografias

Fonte: A partir dos dados encontrados em Instagram (2019).

\section{Registros em vídeos}

No período do mês de abril a \#quemfezminhasroupas retornou 22 vídeos produzidos e postados por diferentes marcas. Após a decupagem, ${ }^{12}$ esses vídeos resultaram em 253 planos de cenas - um plano em sequência, 11 em plano americano, $39 \mathrm{em}$ plano conjunto, seis em meio primeiro plano, $48 \mathrm{em}$ primeiro plano, quatro em primeiríssimo plano e 144 em plano detalhe.

As postagens em vídeos revelaram ângulos parecidos com os registros fotográficos analisados anteriormente. Contudo, as imagens forneceram um ângulo ainda mais fechado no profissional e sua máquina ou ferramenta de trabalho, ao ponto de ser frequente cortar da cena boa parte de seus corpos, como por exemplo, braços, costas, cabeça etc., ou ainda passarmos o vídeo inteiro visualizando apenas mãos no processo de produção das peças.

12 Decupagem significa destrinchar as cenas e enquadramentos do vídeo frame a frame. 

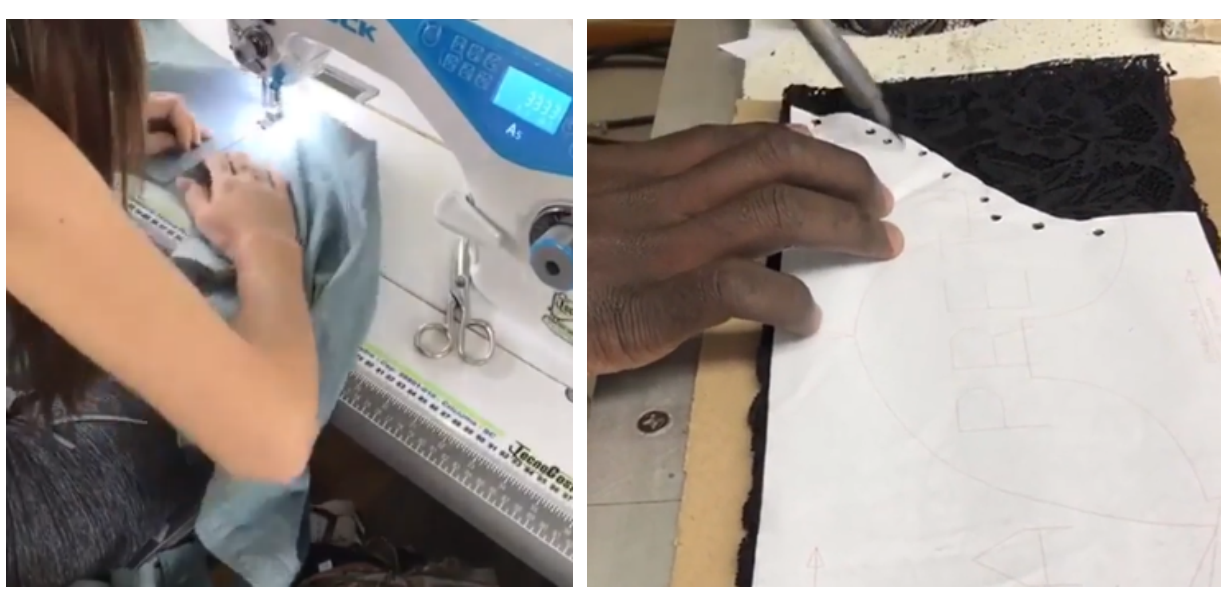

Figura 6. Frame de vídeos incluídos na amostra

Fonte: Instagram (2019).

Apenas 50 frames dessas imagens encaixaram as pessoas em cena sem recortes pelas laterais esquerda ou direita de parte de seus ombros, costas e tronco ou, ainda, recortes pela margem superior de parte da cabeça, sendo: a) três imagens em que aparecem trabalhando atrás de uma enorme mesa, b) três onde visualizamos maquinário ou manequim à frente da pessoa e cobrindo parte de seu corpo, c) nove recortes que mostravam apenas os rostos das pessoas, d) quatro recortes onde mesmo sem cortar a pessoa não é possível visualizar seu rosto, pois elas estão posicionadas de costas, e) três composições onde as pessoas aparecem fora do ambiente de produção com parede branca ao fundo dando relatos individuais sobre a experiência de trabalhar na empresa, f) 26 em plano conjunto com as pessoas segurando placas da campanha em pé com o ambiente de confecção compondo o background, g) por fim, dois vídeos gravados em plano sequência. ${ }^{13}$

No primeiro, há uma mulher de costas sentada em um banco, costurando e conversando com outra mulher que filma. No segundo, uma mulher caminha pelo atelier filmando e mostrando o processo de costura. É possível visualizar o ateliê e toda a estação de trabalho, entretanto, trata-se de uma estação não regulável e a profissional encontra-se sentada em cadeira de madeira.

Face ao exposto, é possível constatar que as imagens não contemplam a aparição dos profissionais envolvidos nos bastidores da moda e seu ambiente de trabalho como um todo, pois nesses 50 recortes em que o enquadramento contemplou a visualização sem corte das pessoas em cena, em apenas cinco deles foi possível obter essa visão como um todo. As outras 45 imagens mesmo estando mais abertas, continuavam dificultando a visualização das pessoas e do espaço de trabalho, pois as pessoas apareciam de costas, fora do ambiente/estação de trabalho ou com imagem fechada apenas em seus rostos.

13 Vídeo o qual todo o conjunto de cenas é gravado de uma única vez sem interrupções. 


\section{DISERTACIONES}

ESTUDIOS

Desse modo, constatamos uma enorme lacuna quanto ao objetivo inicial da campanha \#quemfezminhasroupas. O movimento abraça a ideia de transparência, de oferecer a oportunidade de visualizar os profissionais envolvidos na fabricação das peças, tenta ampliar a compreensão a respeito do complexo ciclo de produção da moda para conscientizar os consumidores e, por fim, tenta oferecer uma oportunidade da marca se mostrar comprometida com o meio ambiente e responsável com seus colaboradores. Desta forma, constatamos que a grande maioria das imagens está distante desses objetivos. Elas são ofertadas em uma lógica de contrato de leitura (Verón, 2005) com aparente adesão à campanha, contudo, revelam pelas imagens que estão mais voltadas para uma estratégia de ciberpublicidade do que com se preocupar em atender as pretensões próprias da campanha em rede \#quemfezminhasroupas.

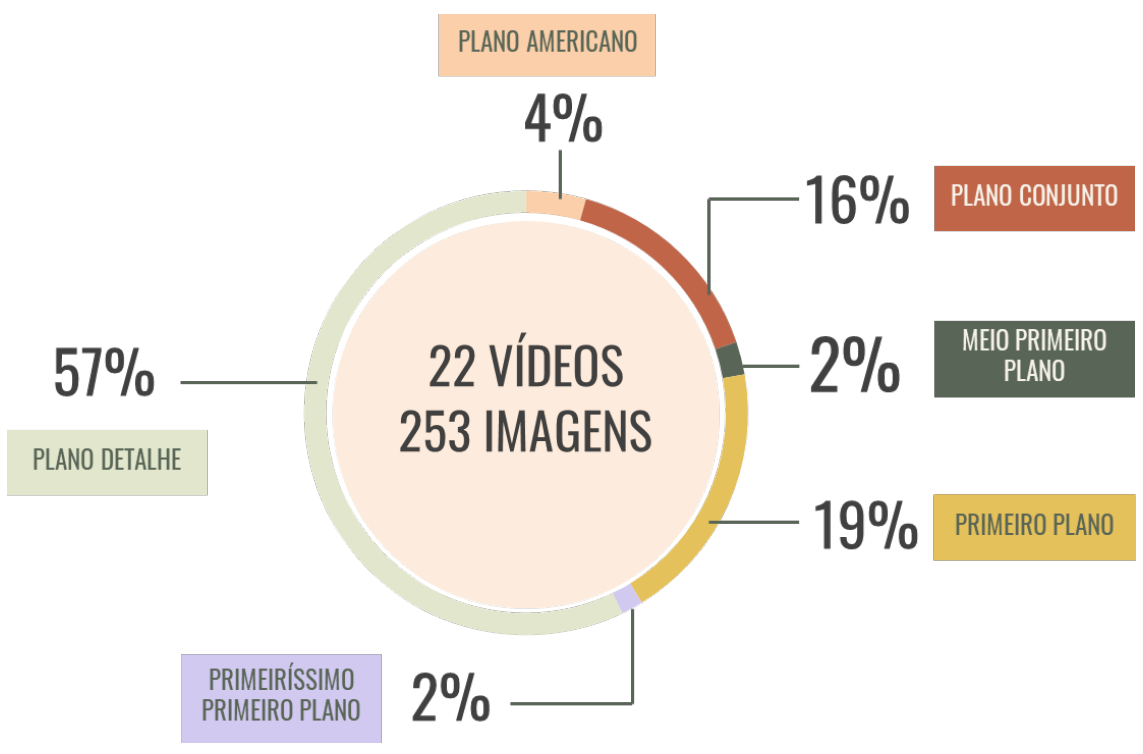

Figura 7. Síntese dos resultados encontrados nos vídeos

Fonte: A partir dos dados encontrados em Instagram (2019).

\section{Textos}

Ao esmiuçar o texto das 297 postagens totais encontradas no mês de abril de 2019, constatamos que em 188 postagens houveram menções às pessoas mostradas nas imagens. As outras 109 sequer nomeavam o profissional. Todavia, apenas 26 desses 188 posts descreveram a pessoa além de sua função na empresa, destacou qualidades além da esfera profissional e revelou em poucas linhas alguma curiosidade sobre a pessoa.

Desse modo, os 168 restantes se concentraram em expor a função da pessoa e destacaram no texto a confecção do produto em si. Nesse caso, o texto girava em torno de mostrar o quanto determinada peça era feita com empenho. Em boa parte dos casos, a pessoa era apresentada quanto a sua função em uma linha e todo o resto do texto falava dos processos que a peça percorreu até ficar pronta. "Vem coisa boa por aí e a Marlene faz parte disso" 


\section{DISERTACIONES}

ESTUDIOS

foi uma das mensagens que chamou a atenção, pois além de destacar o produto, já fez um convite explícito à compra. Outro exemplo que podemos citar, apresenta um texto em que se enunciava o nome da pessoa e sua função, no entanto, a imagem mostrava suas mãos em processo de costura. Claramente, a pessoa foi reduzida a ser apenas a representação de suas mãos vinculada à máquina.

A campanha \#quemfezminhasroupas orientou por tutorial que fosse contado um pouco sobre as pessoas envolvidas no processo produtivo da moda. Conquanto, contar história não foi entendido como construir uma narrativa que empodera e dá visibilidade identitária ao profissional responsável pela fabricação, mas uma operação discursiva que, em sua maioria, se reduzia a dísticos que rotulavam o nome, a função e evidenciavam o produto.

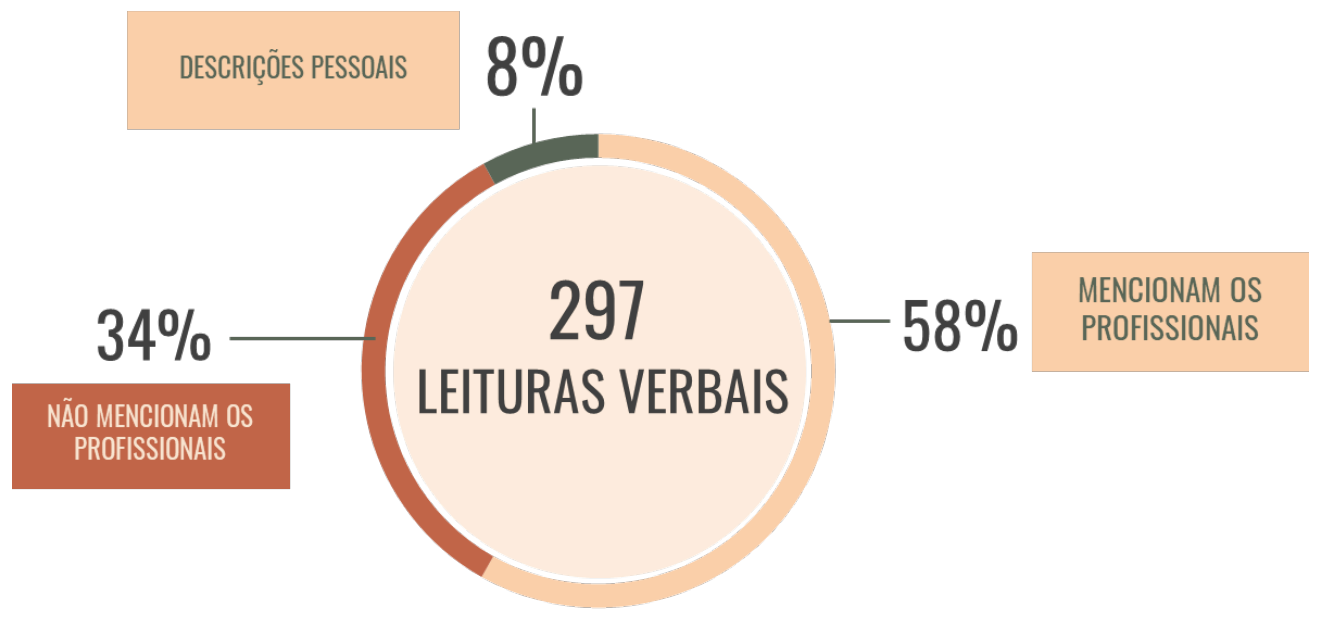

Figura 8. Síntese dos resultados encontrados nos textos

Fonte: A partir dos dados encontrados em Instagram (2019).

\section{Considerações finais}

A análise dessas imagens pode evidenciar o quanto a indústria da moda abriu suas portas, nos convidando a conhecer seus processos, pessoas e ambientes. No entanto, os resultados destacaram mais os processos e produtos do que as pessoas e os ambientes. A maioria das marcas optou por valorizar suas peças destacando o quanto sua confecção foi feita com primazia e em muitas etapas.

Ao dar protagonismo ao desenvolvimento em si, buscou-se uma valorização do produto perante o público, que produziu, por sua vez, um efeito de apagamento dos sujeitos que confeccionaram o produto. É certo que faz parte de um pensamento sustentável em moda a valorização de sua cadeia produtiva. Mas essa valorização não deve acontecer de forma isolada, pois a conscientização de valorização da indústria da moda não gira apenas em torno do preço etiquetado nas peças. Como foi mostrado, campanhas como a \#quemfezminhasroupas buscam cultivar no mercado da moda valores e comprometimento que vão além da qualidade do produto. 


\section{DISERTACIONES}

Não é possível afirmar o quanto essas marcas realmente seguem os ideais da campanha estudada neste artigo, à qual procuraram espontaneamente vincular-se. Mas, é possível diagnosticar através do comportamento da hashtag da campanha que a porta de acesso ao backstage, que era para ser aberta aos usuários, transformou-se em apenas uma brecha. Continuamos sem saber quem são essas pessoas e, principalmente, em que condições elas trabalham.

O tutorial da campanha divulgado na página do movimento Fashion Revolution orientava a contar histórias e mostrar os ambientes de trabalho. Por esse viés, seria possível destacar o lado humano e oferecer protagonismo aos profissionais envolvidos. Em outras palavras, o apelo da campanha deveria ser para humanizar esse processo e mostrar que essas pessoas trabalham em condições dignas. Nesse caso, o processo e o produto também apareceriam, mas de forma coadjuvante. Contudo, a forma como aderiram à campanha foi exatamente o contrário disso. Em vez de humanizar as práticas e apresentar os profissionais como sujeitos do processo de qualidade das marcas, tornaram as pessoas dísticos da mise en scène produzida, contradizendo o contrato de leitura ofertado (Verón, 2005).

Existe um conflito de objetivos que precisam ser alinhados entre marcas e a campanha proposta. A página no Instagram do movimento, em seu tutorial, nos deixa a ideia de que o objetivo da campanha diz respeito às pessoas e ao ambiente de trabalho, no site do Fashion Revolution, o objetivo da campanha aparece como: "conscientizar sobre os impactos socioambientais do setor, celebrar as pessoas por trás das roupas, incentivar a transparência e fomentar a sustentabilidade" (Fashion Revolution, s. f.).

Em contato por e-mail, a ong Fashion Revolution nos ratifica o compromisso da campanha que é: "mostrar quem são as pessoas que estão por trás da produção da nossa roupa, como um primeiro passo para fomentar a transparência na cadeia de moda". No entanto, há nuances de diferenças significativas entre o que acontece na prática de uso da hashtag como oferta do contrato de leitura em questão, baseado nos objetivos expostos pelo movimento. Ou seja, podemos visualizar na maioria das marcas que aderiram à campanha em abril de 2019 estratégias de Branded Content que buscam engajar a partir de um apelo e compromisso com sua responsabilidade social, mas para corresponder aos objetivos da \#quemfezminhasroupas elas precisam ir mais além a partir dos pontos citados no decorrer dessa pesquisa.

As postagens realizadas por diferentes marcas oriundas da hashtag estudada deixaram bastante a desejar no quesito transparência, pois seus ângulos e enquadramentos abriram apenas uma pequena fresta sobre essas pessoas que pouco mostravam de suas instalações, suas histórias e condições de trabalho. Além disso, seus textos, como diagnosticado, buscavam promover as peças, a marca, estimulando o consumo. Não há como falar ao certo a razão da predileção por ângulos que pouco revelam; ou o motivo de pessoas serem reduzidas e cortadas nos formatos de enquadramento; nem tão pouco o porquê do desejo de integrar de forma uníssona máquina e pessoa em imagens registradas de forma tão fechadas em ângulos que um parecia extensão do outro, num processo de objetificação dos sujeitos trabalhadores. Seria a hesitação em nos revelar mais de suas instalações e suas condições de trabalho? Seria o olhar de quem registrou a cena que vê trabalhadores como engrenagens/extensões dessas máquinas?

O escopo do trabalho demandou esforços para compreender através das postagens como as marcas de moda aderiram à campanha no Instagram. As constatações que chegamos provocam inquietações e abrem possibilidades de mais questionamentos. Fica a sensação de que foi mostrado muito pouco e que a transparência na moda ainda 


\section{DISERTACIONES}

ESTUDIOS

Economía de la atención: datos, redes sociales y consumos digitales

ISSN: 1856-9536

Doi: https://doi.org/10.12804/revistas.urosario.edu.co/disertaciones/a.1057.3

Volumen 15, Número 2 / Julio-diciembre 2022

Versión PDF para imprimir desde

http://revistas.urosario.edu.co/index.php/disertaciones

tem um longo caminho a percorrer. Nesse panorama, a força da ciberpublicidade pode ser útil tanto para transparecer quanto para maquiar. A sustentabilidade é um tema que vem, cada vez mais, ganhando relevância e, por esse motivo, se tornando um discurso interessante na busca pelo engajamento dos usuários. A produção de conteúdo em rede acontece dentro de uma lógica "de importância - não há tempo para se perder com o que não tem relevância; e de êxtase - o frisson de intercâmbio intenso daquilo que é virtualmente importante cria um contexto de experiência" (Atem et al., 2015, p.11). Resta às pessoas um olhar crítico que seja capaz de apurar tais circunstâncias.

De acordo com Machado et al. (2017) "no cenário de múltiplas plataformas de comunicação, onde as narrativas se entrecruzam, por vezes o discurso publicitário não é explícito" (p.14). Por isso, as autoras defendem a inserção do aprendizado da literacia publicitária no contexto da educação básica com o intuito de formar uma sociedade mais crítica perante as novas ferramentas e contextos da publicidade contemporânea.

Por fim, ressalta-se que perante um cenário onde as marcas encontram resistência, enquanto objeto, para serem compreendidas como mídias (Trindade \& Perez, 2016), esse estudo buscou contemplar a marca como "dispositivo sócio-técnico-discursivo-comunicacional" e contribuir nessa perspectiva. Do ponto de vista prático, as lacunas encontradas nessa pesquisa podem evidenciar ao mundo das marcas de moda detalhes que podem ser fortalecidos em sua comunicação e práticas sociais. A temática não se esgota nesse artigo e outros questionamentos se formam acerca do assunto que podem ser alvo de investigações futuras, como por exemplo, o porquê da preferência das marcas por certos tipos de conteúdos e composições para se inserirem no contexto da \#quemfezminhasroupas ou, ainda, o que explica o comportamento dos usuários perante esse fluxo de conteúdo são algumas de inúmeras possibilidades de continuar e complementar essa pesquisa.

\section{Referências}

1. Abit. (s. f.). Perfil do sector. https://www.abit.org.br/cont/perfil-do-setor

2. Atem, G. N., Oliveira, T. M., \& Azevedo, S. T. (Orgs.). (2014). Ciberpublicidade: discurso, experiência e consumo na cultura transmidiática. E-papers.

3. Bardin, L. (2016). Análise de conteúdo. Edições 70.

4. Casaqui, V. (2006). Contratos comunicativos da comunicação publicitária contemporânea: sentidos da produção e do consumo nas estratégias de publicização. Em G. N Atem, T. M. Oliveira \& S. T. Azevedo (Orgs.), Ciberpublicidade: discurso, experiência e consumo na cultura transmidiática (pp. 31-47). E-papers.

5. Campos, C. J. G. (2004). Método de análise de conteúdo: ferramenta para a análise de dados qualitativos no campo da saúde. Revista Brasileira de Enfermagem, 57(5), 611-614. https://doi.org/10.1590/ S0034-71672004000500019

6. Carrera, F. (2018). Marcas humanizadas. Appris Editora.

7. Castillo-Abdul, B., Bonilla-Del-Río, M., \& Núñez-Barriopedro, E. (2021). Influence and relationship between branded content and the social media consumer interactions of the luxury fashion brand Manolo Blahnik. Multidisciplinary Digital Publishing Institute, 9(1), 10, 1-15. https://doi.org/10.3390/publications9010010

8. Cruz, P. (14 agosto, 2015). Em ação, ong exige cota para negros na São Paulo Fashion Week. Veja. https:// veja.abril.com.br/cultura/em-acao-ong-exige-cota-para-negros-na-sao-paulo-fashion-week/ 


\section{DISERTACIONES}

ESTUDIOS

Economía de la atención: datos, redes sociales y consumos digitales

ISSN: 1856-9536

Doi: https://doi.org/10.12804/revistas.urosario.edu.co/disertaciones/a.10573

Volumen 15, Número 2 / Julio-diciembre 2022

Versión PDF para imprimir desde

http://revistas.urosario.edu.co/index.php/disertaciones

9. Ellen Macarthur Foundation. (s. f.). Redesigning the future of fashion. https://ellenmacarthurfoundation. org/topics/fashion/overview?utm_source=CFI+Report+Launch+Brazil+Contacts\&utm_campaign=f07df3ae48-EMAIL_CAMPAIGN_2017_11_28\&utm_medium=email\&utm_term=0_19bd7eab25-f07df3ae48-87614613

10. Fashion Revolution. (s. f.). Fashion Revolution Brazil. https://www.fashionrevolution.org/south-america/ brazil/

11. G1. (20 maio, 2009).sPFw quer cota de 10\% de modelos negros em desfiles. Globo.com. https://g1.globo.com/ Noticias/SaoPaulo/0,,MUL1161691-5605,00-SPFW+QUER+COTA+DE+DE+MODELOS+NEGROS+EM+DESFILES.html

12. Goffman, E. (1981). Estigma, notas sobre a manipulação da identidade deteriorada. Guanabara.

13. Gonzalez, M. (5 maio, 2019). Racismo, gordofobia e assédio moral: funcionários denunciam marca carioca. Universa uol. https://www.uol.com.br/universa/noticias/redacao/2019/05/20/racismo-gordofobia-e-assedio-moral-funcionarios-denunciam-marca-carioca.htm

14. Instagram. (2021). Facebook for business. https://business.instagram.com/?locale=pt_BR

15. Jenkins, H. (2009). Cultura da convergência. Aleph.

16. Johnson, R. M. (2015). LVMH, Boosting Women. At LVMH, women were seriously underrepresented in senior positions. Business of Fashion BOF. https://www.businessoffashion.com/articles/news-analysis/ lvmh-boosting-women

17. Lemos, A. (2005). Ciber-cultura-remix. https://www.facom.ufba.br/ciberpesquisa/andrelemos/remix.pdf

18. Levy, P. (1999). Cibercultura. Editora 34.

19. Machado, M., Burrowes, P., \& Rett, L. (06-09 de junho de 2017). Para ler a publicidade expandida: em favor da literacia midiática para análise dos discursos das marcas. Encontro Anual da Compós, São Paulo, Brasil. https://www.compos.org.br/busca_anais.php?idEncontro=MjY=\&termoBusca=Para\%20ler\%20a\%20 publicidade\%20expandida:\%20em\%20favor\%20da\%20literacia\%20midi\%C3\%A1tica\%20para\%20 an\%C3\%A1lise\%20dos\%20discursos\%20das\%20marcas

20. Malmelin, N. (2010). What is advertising literacy? Exploring the dimensions of advertising literacy. Journal of Visual Literacy, 29(2), 129-142.

21. Martins, T. (2019). Moda e ativismo - como o posicionamento das marcas pode afetar os seus resultados (Dissertação de mestrado, Universidade do Minho). http://hdl.handle.net/1822/70452

22. Nunes, J. (1993). Erving Goffman, a análise de quadro e a sociologia da vida quotidiana. Revista Crítica de Ciências Sociais, 37, 33-49.

23. O Globo. (23 maio, 2019). Rihana se torna a primeira mulher negra a comandar grife de luxo: 'momento histórico'. O Globo. https://oglobo.globo.com/ela/moda/rihanna-se-torna-primeira-mulher-negra-comandar-grife-de-luxo-momento-historico-23687605

24. Pereira, R. (2019). Moda, comunicação e consumo: Estudo da marca e novos consumidores sob a perspectiva de um novo cenário (Dissertação de mestrado, Universidade Fernando Pessoa). https://bdigital.ufp.pt/ handle/10284/7753

25. Perez, C. (2009). O fim do target: identidade e consumo na pós-modernidade. Ipsos Marketing. 


\section{DISERTACIONES}

ESTUDIOS

Economía de la atención: datos, redes sociales y consumos digitales

ISSN: 1856-9536

Doi: https://doi.org/10.12804/revistas.urosario.edu.co/disertaciones/a.10573

Volumen 15, Número 2 / Julio-diciembre 2022

Versión PDF para imprimir desde

http://revistas.urosario.edu.co/index.php/disertaciones

26. Perez, C. (05-09 de setembro de 2016). Ecossistema publicitário: o crescimento sígnico da publicidade. Congresso Brasileiro de Ciências da Comunicação, São Paulo, Brasil. http://www3.eca.usp.br/sites/default/ files/form/biblioteca/acervo/producao-academica/002785638.pdf

27. Perez, C., \& Aquino, V. (2018). Estética do consumo: Uma perspectiva a partir da ecologia publicitária. Revista Visualidades, 16(2), 301-318.

28. Perez, C., \& Trindade, E. (2018). Três dimensões para compreender as mediações comunicacionais do consumo na contemporaneidade. Revista Matrizes, 13(3), 109-126. https://www.revistas.usp.br/matrizes/ article/view/165404/158548

29. Querino, R. (2019). Modelo trans se veste de "angel" da Victoria's Secret em protesto contra a marca. Observatorio G. https://observatoriog.bol.uol.com.br/noticias/2018/12/modelo-trans-se-veste-de-angelda-victorias-secret-em-protesto

30. Recuero, R. (2009). Redes sociais na internet. Sulina.

31. Sachs, I. (2004). Desenvolvimento includente, sustentável, sustentado. Garamond.

32. Silva, M., \& Costa, L. (2017). Publicidade, empoderamento feminino e o reposicionamento da cerveja Itaipava. Revista Temática, 13(9), 36-54.

33. Santaella, L. (2013). Comunicação ubíqua: Repercussões na cultura e na educação. Paulus.

34. Socialbakers. (2021). Most importante media trends to remember in 2019. https://www.socialbakers.com/ blog/most-important-social-media-trends-to-remember-in-2019

35. Trindade, E., \& Perez, C. (07-10 de junho de 2016). Lugar do sujeito consumidor entre mediações e midiatizações do consumo: Uma perspectiva latino-americana. Encontro Anual da Associação Nacional dos Programas de Pós-Graduação em Comunicação, Goiania, Brasil. http://www3.eca.usp.br/sites/default/files/ form/biblioteca/acervo/producao-academica/002773893.pdf

36. Vargas, C. (2018). Branding como ferramenta de posicionamento para marcas de moda sustentável: 0 caso Mudha Eco Fashion (Trabalho de conclusão de curso, Universidade de Santa Cruz do Sul). http://hdl. handle.net/11624/2202

37. Veja. (11 novembro, 2018). Victoria's Secret se desculpa por comentários sobre modelos trans. Veja. https://veja.abril.com.br/cultura/victorias-secret-se-desculpa-comentarios-sobre-modelos-trans/

38. Verón, E. (2004). A publicidade ou os mistérios da recepção. Em Autor, Fragmentos de um tecido (pp. 264-272). Unisinos.

39. Verón, E. (2004). As mídias na recepção: desafios da complexidade. Em Autor, Fragmentos de um tecido (pp. 273-284). Unisinos. 